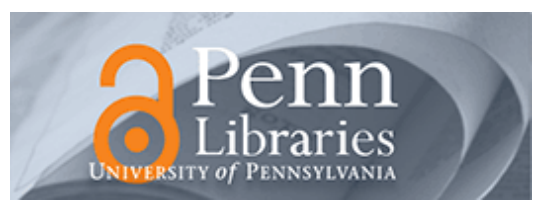

Manuscript Studies

Volume 1

Issue 2 Fall 2017

Article 8

2017

\title{
Canons, Huguenots, Movie Stars, and Missionaries: A Breviary's Journey from Le Mans to Reno
}

Lisa Fagin Davis

Medieval Academy of America, Ifd@themedievalacademy.org

Follow this and additional works at: https://repository.upenn.edu/mss_sims

Part of the Medieval Studies Commons

\section{Recommended Citation}

Davis, Lisa Fagin (2017) "Canons, Huguenots, Movie Stars, and Missionaries: A Breviary's Journey from Le Mans to Reno," Manuscript Studies: Vol. 1 : Iss. 2 , Article 8.

Available at: https://repository.upenn.edu/mss_sims/vol1/iss2/8

This paper is posted at ScholarlyCommons. https://repository.upenn.edu/mss_sims/vol1/iss2/8

For more information, please contact repository@pobox.upenn.edu. 


\title{
Canons, Huguenots, Movie Stars, and Missionaries: A Breviary's Journey from Le Mans to Reno
}

\author{
Abstract \\ This essay traces the journey of a breviary from the cathedral of Le Mans to the University of Nevada at \\ Reno (ND2895.R46 U65 1400z). Liturgical evidence situates the original provenance of the University of \\ Nevada manuscript securely in Le Mans and argues it was intended for display in a niche in the cathedral \\ wall until 1562 when Huguenots sacked Le Mans. Although no definitive evidence of the manuscript is \\ provided in the inventory made by the canons for the purpose of restitution, the manuscript does provide \\ evidence for subsequent ownership. A nineteenth-century document pastedown on the back cover \\ suggests that the manuscript traveled to England some time in the 19th century, where it was likely \\ purchased by Gareth Hughes, the early Hollywood film star turned missionary, who later donated his \\ collection to the University of Nevada in 1964.
}

\section{Keywords}

manuscript studies, provenance, Gareth Hughes, breviary, Le Mans, Reno, missionary, University of Nevada, St. Julian of Le Mans, liturgy 
Davis: Canons, Huguenots, Movie Stars, and Missionaries

\section{MANUSCRIPT STUDIES \\ A Journal of the Schoenberg Institute for Manuscript Studies}

VOLUME 1, NUMBER 2

(Fall 2016)

Manuscript Studies (ISSN 2381-5329) is published semiannually

by the University of Pennsylvania Press

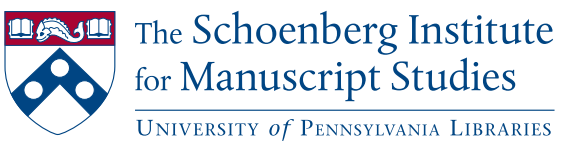




\section{MANUSCRIPT STUDIES}

VOLUME 1, N UMBER 2

(Fall 2016)

\section{ISSN 2381-5329}

Copyright (C) 2016 University of Pennsylvania Libraries and University of Pennsylvania Press. All rights reserved.

Published by the University of Pennsylvania Press, 3905 Spruce Street, Philadelphia, PA 19104.

Printed in the U.S.A. on acid-free paper.

Manuscript Studies brings together scholarship from around the world and across disciplines related to the study of premodern manuscript books and documents, with a special emphasis on the role of digital technologies in advancing manuscript research. Articles for submission should be prepared according to the Chicago Manual of Style, $16^{\text {th }}$ edition, and follow the style guidelines found at http://mss.pennpress.org.

None of the contents of this journal may be reproduced without prior written consent of the University of Pennsylvania Press. Authorization to photocopy is granted by the University of Pennsylvania Press for libraries or other users registered with Copyright Clearance Center (CCC) Transaction Reporting Service, provided that all required fees are verified with CCC and paid directly to CCC, 222 Rosewood Drive, Danvers, MA 01923. This consent does not extend to other kinds of copying for general distribution, for advertising or promotional purposes, for creating new collective works, for database retrieval, or for resale.

\section{SUBSCRIPTION INFORMATION:}

Single issues: $\$ 30$

Print and online subscriptions: Individuals: $\$ 40$; Institutions: $\$ 90 ;$ Full-time Students: $\$ 30$ International subscribers, please add $\$ 18$ per year for shipping.

Online-only subscriptions: Individuals: \$32; Institutions: \$78

Please direct all subscription orders, inquiries, requests for single issues, address changes, and other business communications to Penn Press Journals, 3905 Spruce Street, Philadelphia, PA 19104. Phone: 215-573-1295. Fax: 215-746-3636. Email: journals@pobox.upenn.edu. Prepayment is required. Orders may be charged to MasterCard, Visa, and American Express credit cards. Checks and money orders should be made payable to "University of Pennsylvania Press" and sent to the address printed directly above.

One-year subscriptions are valid January 1 through December 31. Subscriptions received after October 31 in any year become effective the following January 1 . Subscribers joining midyear receive immediately copies of all issues of Manuscript Studies already in print for that year.

Postmaster: send address changes to Penn Press Journals, 3905 Spruce Street, Philadelphia, PA 19104.

Visit Manuscript Studies on the web at mss.pennpress.org. 


\title{
Canons, Huguenots, Movie Stars, and Missionaries
}

A Breviary's Journey from Le Mans to Reno

\author{
Lisa FAgin Davis \\ The Medieval Academy of America
}

\begin{abstract}
Ometime in the first half of the fifteenth century, a canon named Guillaume Thébard gave a breviary to the Cathedral of Le Mans for the use of clerics who were too poor to purchase their own liturgical books. The breviary was displayed in a pulpit-like niche measuring $54 \times 36$ $\mathrm{cm}$ that was carved into the south side of the first southern pillar of the Choir, facing the ambulatory, where clerics could privately refer to it in advance of saying the office (fig. 1). The niche is surmounted by an inscription describing the donation: "Magister Guill. Thebardi Hujus Ecc. / Canonicus Dedit Istud Breviarium Pro Usu / Indegencium. Orate Deum Pro Eo" ("I, Master Guillaume Thébard, Canon of this Church, give this breviary for the use of the indigent. Pray to God for him"). The holes around the perimeter of the niche indicate that the manuscript was once protected by a grille of metal bars, so no chain was necessary to secure it. The user could reach through the grille to turn the pages. ${ }^{1}$
\end{abstract}

1 Thébard made several donations to the Cathedral, beginning in 1407. See Paul Piolin, Histoire de l'église du Mans, 6 vols. (Paris: Julien, Lanier, et al., 1851-1863), 5:74; "Bréviaire Publique, au Mans," Magasin Pittoresque 37 (1869): 180; Ambroise Ledru and Gabriel Fleury, La Cathédrale Saint-Julien du Mans: Ses évêques, son architecture, son mobilier (Mamers: Fleury 


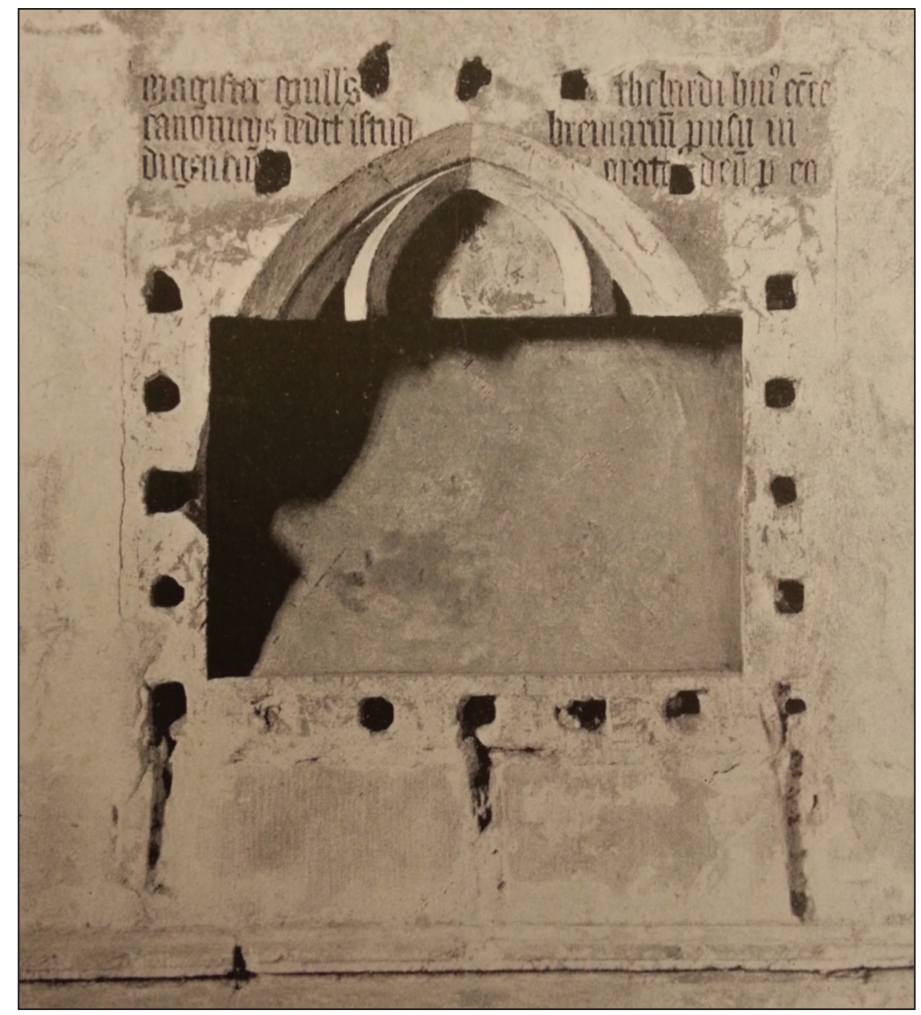

FIGURE 1. Le Mans Cathedral Book-Niche. Reproduced from Amboise Ledru and Gabriel Fleury, La Cathédrale Saint-Julien Du Mans: Ses Évèques, Son Architecture, Son Mobilier (Mamers: Fleury \& Dangin, 1900), 447.

Today, just such a breviary for the use of Le Mans belongs to the University of Nevada at Reno, which holds two pre-1600 codices and more than two dozen leaves. The breviary, which also includes a ferial psalter, dates from around the year 1440 and may be the very breviary that once sat in the

et Dangin, 1900), 447; André Mussat, La Cathédrale du Mans (Paris: Berger-Levrault, 1981), 151; Michel Bouttier, La Catbédrale du Mans (Le Mans: La Reinette, 2000), 117. For other examples, see Mary Kay Duggan, "The Psalter on the Way to the Reformation," in The Place of the Psalms in the Intellectual Culture of the Middle Ages, ed. Nancy Elizabeth Van Deusen (Albany: State University of New York Press, 1999), 153-90 at 175; Philippe Cordez, "Le lieu du texte: Les livres enchaînés au Moyen Âge,” Revue Mabillon 17 (2006): 75-103. 


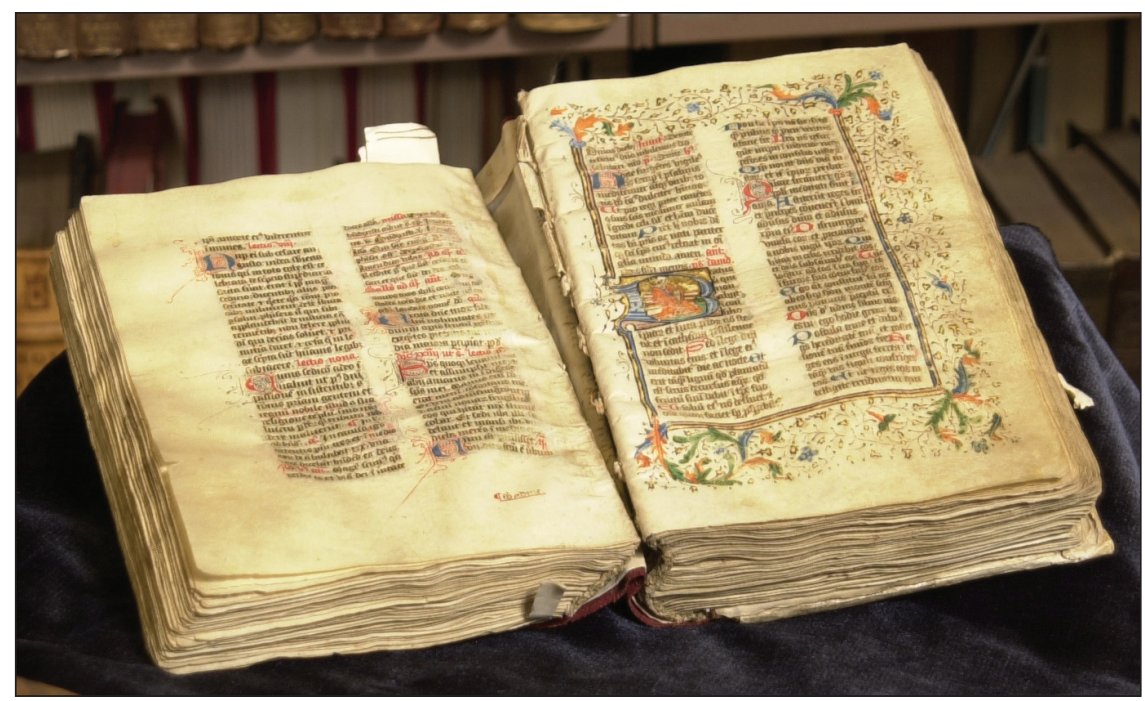

FIGURE 2. The Reno Breviary (Reno, University of Nevada, Special Collections, ND2895.R46 U65 1400z). Reproduced by permission of Special Collections, University of Nevada, Reno.

cathedral's niche. The identification is circumstantial, but is supported by the history of the manuscript as well as its codicological features. It is not only the manuscript's origin that is of interest; just as intriguing is its journey to Nevada.

The Reno codex measures 190 x 135 mm (fig. 2). It currently comprises 342 folios but is lacking at least thirteen whole leaves and perhaps as many as thirty, along with the outer half of several leaves (a description of the manuscript is appended to this article). Offsets on facing pages indicate that each of the missing outer halves included an illuminated initial, for example, at Christmas, Easter, and eight of the nine psalter divisions. Extant leaves show how the missing sections were illuminated, with rinceaux, flowers, and buds typical of the time and place. The breviary begins at the First Sunday of Advent with an historiated initial of the Annunciation, and the psalter begins, as expected, with David at his harp. Both initials are heavily rubbed and damaged, but were once delicate and bright (fig. 3).

The boards are original and have been repaired several times with later paper, rebacked in modern red velvet. The spine is broken, and entire 

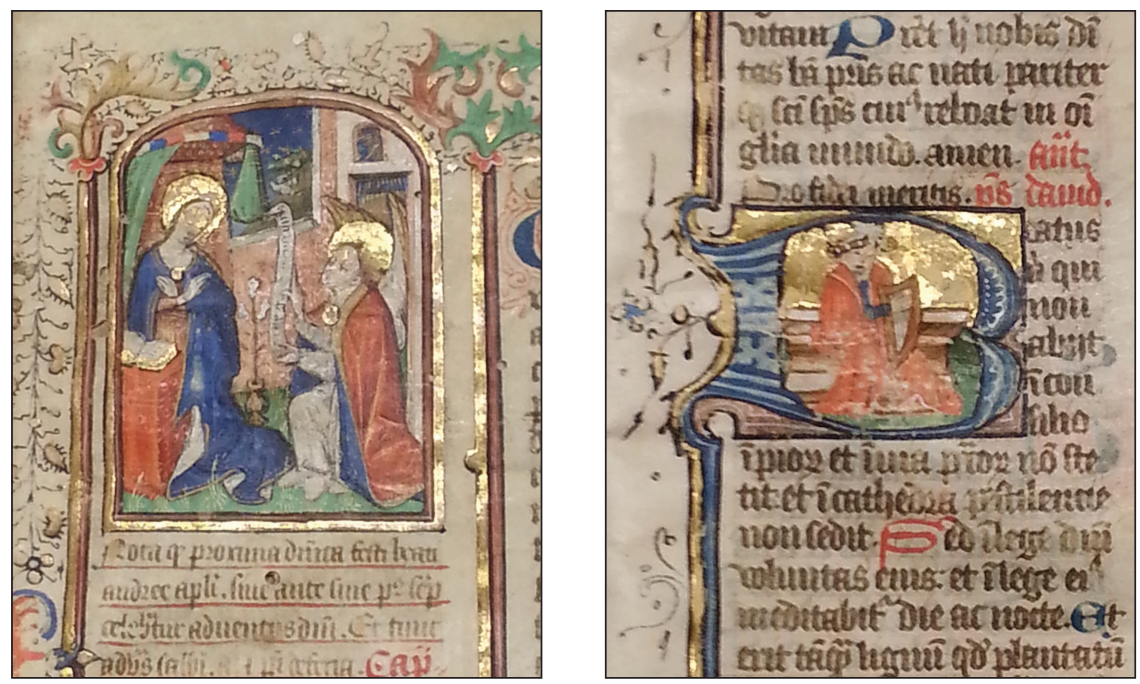

FIGURE 3. Annunciation, from the Reno Breviary, fol. 1 (left) and David playing the harp, from the Reno Breviary, fol. 129 (right).

quires are missing; the Sanctorale is lacking sections for February through March and September through December. The book ends imperfectly (in the middle of August of the Sanctorale), and any flyleaves that may have been at the end have been lost. As damaged as it is, enough of the sanctorale and litany survive to definitively localize the manuscript. The preponderance of liturgy devoted to the veneration of St. Julian of Le Mans, including his translation, places the manuscript in the Cathedral in Le Mans, France, southwest of Paris: the temporale Office for the Dedication of the Church (fol. 73v) includes liturgy for the translation of St. Julian; the sanctorale includes saints of Le Mans import including Domnolus (1 December), Gervasius and Prothasius (Le Mans date of 13 December as well as feast and octave), Gatianus (18 December), Thuribus (16 April), Austregisilus (20 May), Caruini (28 May), Bertrannus (translation, 6 June), Pavacius (24 July and translation on 9 July), and, of course, St. Julian (translation, 25 July). The manuscript is interesting in and of itself-not only are there very few known liturgical manuscripts that can be so clearly associated with Le Mans, but of those, the Reno breviary is 


\section{Davis: Canons, Huguenots, Movie Stars, and Missionaries}

the earliest. ${ }^{2}$ There is no way to know for certain whether the Reno breviary is in fact the very manuscript given by Thébard and stored in the niche, but of the group of breviaries known to be associated with the Cathedral in the fifteenth century, this is the only viable candidate. The Reno breviary is the right type of book from the right place, it is of the right date, and, when open, it would have fit neatly into the Le Mans cathedral niche.

The breviary given to the cathedral by Guillaume Thébard was safely ensconced behind bars in that niche for more than a century, until May of 1562, when the Le Mans cathedral was sacked by the Huguenots. The surviving Canons quickly filed a suit of restitution that included a very detailed inventory of what was looted or destroyed. ${ }^{3}$ The booty included ivories, jewels, textiles, printed books, and manuscripts, although the books are not described in enough detail to provide any definitive identifications. ${ }^{4}$ The rebels also stole a significant amount of metalwork and window-grilling that may have included the metal bars that protected the niche. ${ }^{5}$ Once the bars were gone, the manuscript would certainly have been next.

It is not clear from the documentary record what happened to the Le Mans breviary after it disappeared from the Cathedral. We must turn to the Reno codex for evidence, where some trace of the next several centuries has been left. The manuscript opens with a flyleaf on which a fifteenth-century woodcut of the Trinity with saints and clerics has been adhered. There is no way to know when this was attached. This leaf is actually the blank first recto of a bifolium that was originally a French document dated 1664. The document has nothing to do with the Cathedral or its denizens; instead, it records a business transaction between laymen, location unknown. The

2 Identified Le Mans breviaries include: Carpentras, Bibl. Municipale, MS 68 (late fifteenth century); Christie's, 14 November 2007, lot 12 (ca. 1450); Le Mans, Bibl. Municipale, MS 136 (s. XV med: see http://bvmm.irht.cnrs.fr/consult/consult.php?reproductionId=3328); London, British Library, Harley 2450 (s. XV 2/2); Paris, Bibl. de l'Arsenal, MS 275; and Paris, Bibliothèque nationale, MS Lat 1302.

3 See "Plaintes et doléances du chapitre du Mans après le pillage de la cathédrale par les Huguenots en 1562," in Archives Historiques du Maine 3 (1903): 169-256.

4 For example, "Item, le temps de l'advent du bréviaire en parchemyn escript à la main et note, vallant deux cens livres tourn., pour ce. iicc l" ("Plaintes et doléances du chapitre du Mans," 206).

5 “Plaintes et doléances du chapitre du Mans," 248-51. 
document was rotated and folded to make a bifolium that was sewn into the codex at an unknown date. It is signed in the style of the time with paraphes instead of signatures, gentlemen thus far unidentified. The bifolium does not represent an original pastedown with a conjoint flyleaf; it has been sewn in before the original blank flyleaf, which is now the third prefatory leaf. The fourth flyleaf is a tipped-in folio from a completely different manuscript, a mid-fifteenth-century book of hours. The breviary itself begins on the next leaf. These added front flyleaves have nothing to do with Le Mans or with the breviary itself, revealing little about the manuscript's journey other than the eclectic tastes of the later owner who added them.

There is evidence at the back of the volume that is indeed relevant to the provenance of the manuscript. A nineteenth-century document used as a paste-down repair inside the lower cover is written in English, and, though fragmentary and lacking a specific date, it can be localized to Lincolnshire, as the text clearly refers to the "county of Lincoln." By sometime in the nineteenth century, then, the manuscript had probably made its way to England. Additional evidence can be found inside the front cover. A small label in the lower outer corner suggests that the manuscript has been through the book market at least once, a sale or catalogue in which it was number 410; there is no identifiable trace of the manuscript in the Schoenberg Database of Manuscripts, however. The final piece of provenance evidence is the signature inside the front cover of an early twentieth-century owner, a silent-movie star from Wales named Gareth Hughes.

Gareth Hughes has never appeared in the cast of characters who populate the world of medieval manuscript provenance in the United States, having never made it into the de Ricci Census or its Supplement. ${ }^{6}$ But he deserves to be remembered, in part because his life story is tribute to the appeal of manuscripts such as the Reno Breviary to both the secular and the faithful. The leaves and codex that he bequeathed to the University of

6 Seymour de Ricci and William J. Wilson, Census of Medieval and Renaissance Manuscripts in the United States and Canada, 3 vols. (New York: Wilson, 1935-1940); and W. H. Bond, C. U. Faye, and Seymour de Ricci, Supplement to the Census of Medieval and Renaissance Manuscripts in the United States and Canada (New York: Bibliographical Society of America, 1962). 


\section{Davis: Canons, Huguenots, Movie Stars, and Missionaries}

Davis, Canons, Huguenots, Movie Stars, and Missionaries

Nevada in Reno perfectly suited the Gothic aesthetic that permeated the first act of his life, lived as a Hollywood darling in the 1920s and 1930s, as well as the faith-based second act as a missionary to the Paiute in Nevada.

Born William John Hughes in 1894, Gareth Hughes was a Welsh actor who made a name for himself on Broadway in the 1910s and in the Hollywood silent film industry of the 1920s. He worked with Clara Kimball Young in 1919's “Eyes of Youth,” a film that also starred Rudolph Valentino, but his greatest success was in 1921's "Sentimental Tommy." Throughout the decade, he enjoyed the lavish and-it is rumored-scandalously promiscuous lifestyle of a Hollywood darling, and his opulent Los Angeles home revealed an early interest in the Gothic aesthetic. ${ }^{7} \mathrm{He}$ traveled to Europe several times in the 1920s, as evidenced by ship manifests to or from England in 1922, 1924, and 1925. Hughes biographer Stephen Lyons argues convincingly that Gareth acquired his manuscripts before the crash of 1929, probably on one of those European sojourns. ${ }^{9}$ He must have acquired them

7 For Hughes's reputation and sexuality, see “Gareth Hughes," Gay History Wiki, http:// gayhistory.wikidot.com/gareth-hughes, accessed 24 May 2015; William J Mann, Bebind the Screen: How Gays and Lesbians Shaped Hollywood, 1910-1969 (New York: Viking, 2001), 19-20; Anthony Slide, Silent Players: A Biographical and Autobiographical Study of 100 Silent Film Actors and Actresses (Lexington: University Press of Kentucky, 2010), 205.

8 Hughes' name appears on the following manifests: S. S. Olympic from Cherbourg to New York City-25-31 October 1922; S. S. President Harding from New York to Plymouth31 August 1924 (arrived); S. S. President Harding from Southampton to New York-12-20 November 1924; and S. S. Rochambeau from La Havre to New York City-9-18 September 1925, among others. See "Gareth Hughes," Gay History Wiki.

9 Personal correspondence, 4 January 2014. For additional information on Hughes, see "Gareth Hughes: Unlikely Missionary to the Paiutes," Online Nevada Encyclopedia, http:// www.onlinenevada.org/articles/gareth-hughes-unlikely-missionary-paiutes, accessed 24 May 2015; and Stephen Lyons, "Gareth Hughes: The First Welsh Film Star," http://intothelonging. com, accessed 24 May 2015. A distant relative of Hughes's named Kelvin Guy has also posted biographical information and a short documentary film about Hughes, although his version of Hughes's life is somewhat more idealized than Lyons's: “Gareth Hughes," http://silentholly wood.com/garethhughes.html, accessed 24 May 2015. An online exhibition of images of Hughes can be found at "Gareth Hughes: A Life in Pictures," Online Nevada Encyclopedia, http://www. onlinenevada.org/gareth-hughes-life-pictures, accessed 24 May, 2015. 
in the 1920s, whether at home or abroad, because the 1929 stock market crash left him essentially penniless. ${ }^{10}$

In spite of facing financial disaster, Hughes continued to act in film and onstage sporadically in the 1930s. To supplement his income, he worked throughout that decade as Director of Shakespearean and Religious Theatre in Los Angeles. It is during this period that he became a man of faith, undergoing for reasons still unknown a significant religious transformation. By the time he registered for the draft in 1944, he had left Los Angeles and was living at 980 Memorial Drive in Cambridge, Massachusetts, the address on his draft card. Gareth had taken monastic vows at the Protestant Episcopal Monastery of the Society of St. John the Evangelist, taking the name "Brother David" (perhaps in honor of St. David, patron of Wales). His manuscripts now must have taken on a different meaning; whereas before he would have been attracted to the Gothic decoration preserved in the breviary and single leaves, the collection would now take on theological significance.

After a brief stint at a Benedictine abbey in New York, Brother David was sent to Nevada in 1944 as a missionary to the Paiute tribe at Pyramid Lake. He served the Tribe as a teacher and pastor with fervor and devotion for more than a decade and is still remembered fondly by the grown children he served. He never lost sight of his theatrical roots, often employing dramatic readings and costumes in his preaching and teaching. While working at Pyramid Lake, Hughes joined the English Department at the University of Nevada in Reno, teaching Shakespeare and contributing a portion of his earnings to the Mission. He frequently exhibited his collection to local bibliophiles, such as the soirée described in this article from the Nevada State Journal under the title "Rare Book Collection Displayed at Meeting":

Specimens from a priceless collection of rare books were displayed by Dr. Gareth Hughes this week at a meeting of the Reno Poetry Workshop held at the home of Mrs. Ray J. Root. Dr. Hughes's

10 Kelvin Guy, “Into the Longing," http://intothelonging.com, accessed 24 May 2015. 
Davis: Canons, Huguenots, Movie Stars, and Missionaries

collection, described as "first rate" by literary authorities at the University of Nevada, includes an original Fourth Folio edition of Shakespeare dating back to the seventeenth century, a Quarto Edition of Shakespeare and a great many other early and rare editions. Workshop members had the pleasure of examining a fifteenth-century breviary written on vellum and bound in velvet and wood. Illustrations of the work are done in gold and lapis, and colors of the illuminations are described as clear and fresh. Dr. Hughes explained the use of the breviary entitled the "Book of Hours," stating it was employed by wealthy families of the period for their private prayer services. ... Dr. Hughes is a former Shakespearian actor with experience both on the legitimate stage and in the early films. He presented several interpretations of Shakespearian characters ... including his version of Shylock and scenes from Richard the Second, which were enthusiastically received. For a closing entertainment, he read Celtic and Gaelic poetry from a collection . . by Fiona MacCloud. . . His delivery of the poems was described as inspirational in meaning and beauty. ... At the close of the evening, refreshments were served by the hostesses. ${ }^{11}$

Setting aside Hughes's misconceptions about the use of a breviary, his enthusiasm for the collection was palpable. Notably, the article was accompanied by an image showing the recto of the book of hours leaf laid in and facing the opening of the Psalter. Today, however, the leaf is tipped in at the very beginning of the manuscript, its verso facing the opening of the breviary. It was not tipped into its current location by the University; it must have been moved up front and attached by Hughes himself. Like this wayward leaf, the otherwise unrelated leaves and documents at the front of the volume seem to have been acquired separately by Hughes and added to the volume as a kind of collection of their own.

11 “Rare Book Collection Displayed at Meeting," Nevada State Journal, 6 January 1946, p. 11. 
While Brother David found his missionary work extremely satisfying, it was exhausting and physically difficult. He left in 1956 and took a position as an officiant at a Reno wedding chapel. ${ }^{12}$ After a brief return to Wales, Hughes retired to California in 1958 to live out his life at the Motion Picture Country Home in Woodland Hills, a retirement community for members of the film industry, reuniting there with some of his old co-stars such as Clara Kimball Young, whom he baptized shortly before her death. ${ }^{13}$ While in California, he continued to be connected to the University in Reno, exhibiting his collection there in the 1960s before donating it to the University in 1964. Hughes died in 1965 of complications from byssinosis, a lint-borne respiratory disease he contracted from years of sorting donated clothing at Pyramid Lake, and his cremated remains were buried at the Masonic Memorial Gardens cemetery in Reno.

In addition to his printed books and the breviary, Hughes donated several manuscript leaves to the University. Because the leaves are co-mingled with later acquisitions, it is not easy to determine which leaves were in fact Gareth's. Fortunately, his manuscripts were with him at the retirement home in California, where he displayed them prominently on the wall of his cottage surrounded by early printed books and mementos of his time among the Paiute. Several of these leaves can in fact be identified among the University's collection: a book of hours leaf, a miniature from a book of hours of Christ in the tomb surrounded by instruments of the Passion, and leaves of two fifteenth-century books of hours, among others (fig. 4). What they all have in common is that Gothic aesthetic that so attracted Hughes throughout his secular movie-star days.

The story of his life as gleaned from various sources only scratches the surface of Gareth Hughes's fascinating journey, a journey on which the

12 See "Gareth Hughes: Unlikely Missionary to the Paiute," Online Nevada Encyclopedia, http://www.onlinenevada.org/articles/gareth-hughes-unlikely-missionary-paiutes, accessed 24 May 2015.

13 “Brother David Is Going Back to Native Land," Nevada State Journal, 25 May 1958, p. 20; and a brief notice reading "Great Shakespearean actor Gareth Hughes (more familiar locally as Bro. David) back from Wales and listing his address as the Motion Picture Country House and Hospital at Woodland Hills," Nevada State Journal, 17 January 1959. 
Davis: Canons, Huguenots, Movie Stars, and Missionaries

Davis, Canons, Huguenots, Movie Stars, and Missionaries

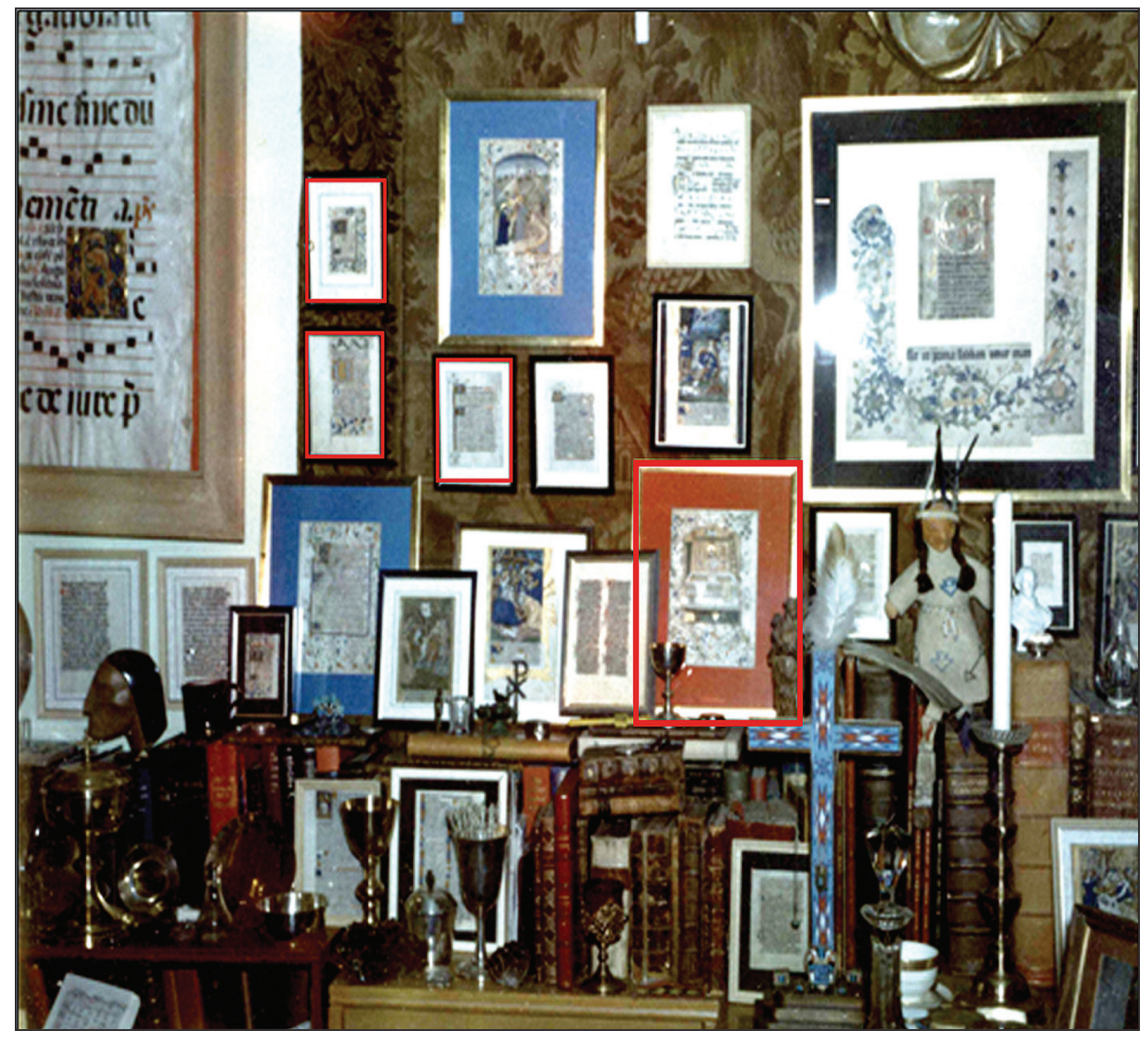

FIGU RE 4. Gareth Hughes' collection displayed at his Woodland Hills, CA, home, with examples of identified leaves from the University of Nevada, Reno's collection outlined in red. Reproduced by permission of Special Collections, University of Nevada, Reno.

Breviary/Psalter was his sometime companion, crisscrossing the country with him as he transformed from a playboy movie star to a man of the cloth (fig. 5). These quotes, gathered from Stephen Lyons's website, seem to perfectly capture the varied facets of Gareth Hughes's life and work: ${ }^{14}$

- Isadora Duncan called him "the world's greatest dancer"

- David Belasco, a legend of American Theatre, thought he brought to mind "green fields, altar candles—and a brothel"

14 Lyons, "Into the Longing." 


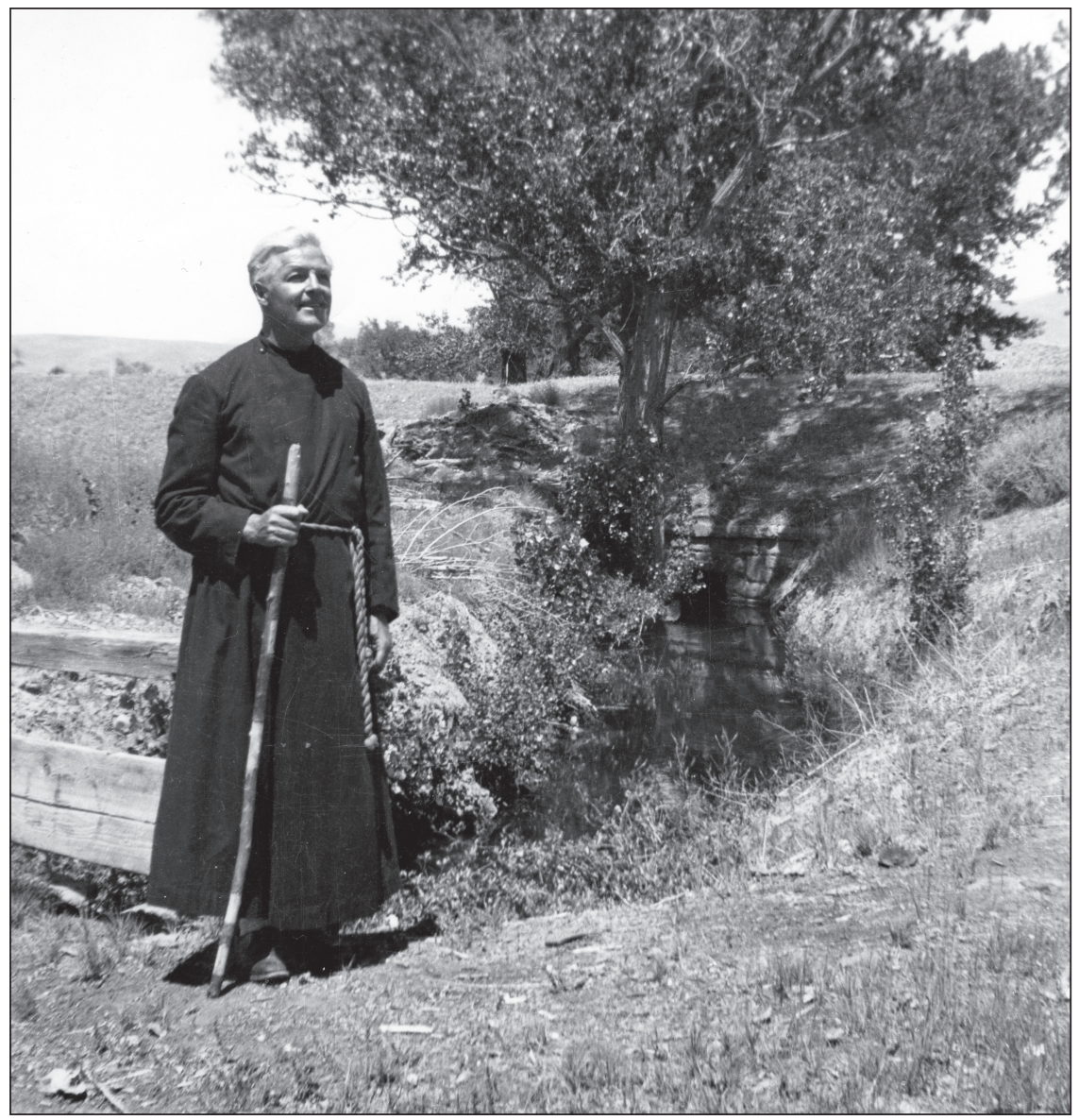

FIGURE 6. Gareth Hughes (a.k.a. "Brother David”) at Pyramid Lake, NV. Reproduced by permission of Special Collections, University of Nevada, Reno.

- Cecil B. DeMille called him the "young idealist"

- The Bishop of Nevada wrote of him, "He is the only white man I have ever known who seems to win immediately the unreserved affection of the Paiute people. He is the most effective teacher of the simple essentials of the Catholic faith I have ever known"

Hughes would certainly have been most proud of the latter. 


\section{Davis: Canons, Huguenots, Movie Stars, and Missionaries}

\section{Appendix}

University of Nevada

Special Collections

Hughes Breviary

Le Mans, ca. 1440

Breviary/Psalter

Nota quod proxima dominica festa beati sancti andree . . . / Ecce virgo concipiet . . . / . . domini exultatione repletus est.

fols. i-ii: $\quad$ French document, s. XVIII (rotated and folded to become a bifolium; because the dorse was blank, the first recto and last verso of the bifolium are blank)

fol. iii: tipped-in leaf from a mid-fifteenth-century book of hours, from Matins of the Hours of the Virgin

fol. iv: original blank flyleaf

fols. 1-128v: Temporale (incomplete, ends with Dom. XXIV post Pent.); the Office for the Dedication of the Church (fol. 73v) includes liturgy for the translation of St. Julian

fols. 129-84v: Psalter (presumably in nine parts, with divisions at Pss 1, 26, 38, 51, 52, $68,80,97$, and 107; the leaves that would have begun the divisions after Ps 1 are lacking, and offsets on facing pages indicate that there were illuminated initials on the missing leaves)

fols. 185-92: Litany and Suffrages (with special emphasis on St. Julian of Le Mans and Sts. Gervasius and Prothasius)

fols. $192 \mathrm{v}-93 \mathrm{v}$ : blank

fols. 194-207v: Commons

fols. 208-342v: Sanctorale (includes Le Mans saints Domnolus (1 December), Gervasius and Prothasius (Le Mans date of 13 December as well as feast and octave), Gatianus (18 December), Thuribus (16 April), Austregisilus (20 May), Caruinus (28 May), Bertrannus (translation, 6 June), Pavacius (24 July and translation on 9 July), Julian (translation, 25 July); incomplete, lacking February through March and September through December, with the final four leaves a slightly later addition of the Office of the Visitation

Parchment codex, iv + 342 fols., 190 x 135 (119 x 82) mm. 2 columns (each 37 mm), 31 lines. 
$1-17^{8}, 18^{8-2}, 19^{8-1}, 20^{8-1}, 21^{8-2}, 22^{8-1}, 23-25^{8}, 26^{8-1}, 27-29^{8}, 30^{8-1}, 31-41^{8}, 42^{8-2}, 43^{8-2}, 44^{8-1}, 45^{4}$. Lacking at least thirteen leaves and several partial leaves, most of which probably included illuminated initials (certainly for Easter, all of the Psalter divisions, and the Nativity), after fols. 136 (Ps 26), 143 (Ps 38), 146 (Pss 51 and 52), 151 (Ps 68), 157 (Ps 80), 162 (Ps 97), 168 (Ps 107), 197, 226 (Nativity), 319, 322, 326, 328, 334; outer half of fol. 63 cut away (initial for Easter); entire quires missing after fols. 128 (one quire), 263, and 338 (at least three quires). Decorative catchwords, lower right corner, final verso of each quire (those at the end of quire 16 [fol. 128v], quire 17 [fol. 135v], quire 34 [fol. 263v], and quire 43 [fol. 338v] do not match; leaves are missing at these points).

Written in a Gothic bookhand in black ink with red and/or underscored rubrics. Six illuminated initials extant (of originally at least sixteen), as follows: fol. 1: twelve-line initial in gold and colors with full border of rinceaux, gold leaves, and buds, historiated with a miniature of the Annunciation (for the First Sunday of Advent); fol. 129: six-line initial in similar scheme with full border, historiated with a miniature of King David playing the harp (for Ps 1); five-line initials in gold and colors with 1/4 border on fols. 291v (Sts. Gervasius and Prothasius), 295v (St. John the Baptist), 317 (Translation of St. Julian of Le Mans), and 330v (the Assumption of the Virgin); in addition, a full border opens the Sanctorale on fol. $208 \mathrm{v}$.

Binding: original half-vellum over wooden boards, spine (broken) covered in red velvet.

Written in Le Mans for the use of the Cathedral of St. Julian of Le Mans (see contents above for details of Le Mans liturgy preserved in the manuscript). S. XIX English document used for repair inside lower cover. Purchased by Gareth Hughes, probably in England, in the 1920s, after which it appears that he added the prefatory leaves. Given by Hughes to the University of Nevada in 1964 . 